\title{
EDITORIAL
}

\section{Improving outcomes after critical illness: harder than we thought!}

\author{
Carol Hodgson ${ }^{1}$ and Brian H. Cuthbertson ${ }^{2^{*}}$
}

๑ 2016 Springer-Verlag Berlin Heidelberg and ESICM

\section{Introduction}

In this edition of Intensive Care Medicine, Nordisk et al. report the results of the RAPIT study [1], a pragmatic, multicenter, randomized controlled trial of a nurse-led individualized intensive care unit (ICU) recovery program compared to standard care. The intervention group received consultations that included a guided illness narrative supported with photographs taken by ICU nurses during ICU care. This trial randomized 386 adults and found no difference in the primary outcome of healthrelated quality of life (QoL). It adds to the growing number of trials that have failed to improve patient-centered outcomes after critical illness (Table 1), and we reflect on factors that may contribute to this state of affairs.

\section{The wrong patients?}

The goal of any intervention is to target a modifiable process. When a heterogeneous group of patients is recruited to a study, including patients with co-morbid conditions, we need to carefully consider their impact on the outcomes at question [2,3]. Pre-existing mental health problems are an important risk factor for poor QoL and for psychiatric diagnoses after critical illness and may interact with physical outcomes in ways we do not yet understand [4]. Similarly, severe chronic physical co-morbidity can interact with acute physical conditions in ways that may prevent or impair the effectiveness of physical rehabilitation strategies $[3,5]$. A recent publication on the heterogeneity of treatment effects encourages us to carefully consider how we perform patient

\footnotetext{
*Correspondence: brian.cuthbertson@sunnybrook.ca

${ }^{2}$ Department of Critical Care Medicine, Sunnybrook Health Sciences

Centre and University of Toronto, 2075 Bayview Avenue, D-wing,

1st floor room D1 08, Toronto, ON M4N 3M5, Canada

Full author information is available at the end of the article

This editorial refers to the article available at

doi:10.1007/s00134-016-4522-1.
}

selection, stratification and analyses for known risk factors [6]. For example, a study of the use of patient diaries suggested that patients at higher risk of psychological morbidity may be the only ones to benefit from a diary intervention [7].

\section{The wrong interventions?}

As always in studies where the primary outcome shows no effect, the most plausible and reasonable conclusion of the study is that the intervention was indeed ineffective. Another hypothesis is that the intervention may have been effective if delivered with a different dose or at a different time point in the patient's trajectory [8]. This latter possibility has been highlighted with the fact that some [9] - but certainly not all-studies of early physical interventions that start in the ICU have shown benefit compared to studies in which interventions commence later when the pathophysiological changes in the patient may be more difficult to reverse [10]. At present, the time point at which to intervene to improve mental health and QoL outcomes is unclear, but a recent systematic review of longitudinal studies reported that there was very little change in depressive symptoms in the 12 months after ICU discharge [4].

\section{The wrong clinical team?}

Previous research has shown that post-intensive care syndrome is complex and so perhaps review by expert physicians should be considered a key part of our multidisciplinary approach [2]. Specifically, the healthcare specialists with the most expertise at improving mental health outcomes are surely mental health specialists. Likewise, the professionals with the greatest expertise for the management of older patients with complex comorbidities following acute conditions are geriatric and rehabilitation specialists. To date, partly due to an inability to engage such specialties, and out of our own genuine

\section{Springer}


desire to help "our" patients, we have tried to design and deliver these interventions in isolation as an intensive care team. It is likely that this should change in the future.

\section{The wrong trial designs?}

Outcome measures Quality of life is the most common outcome in such trials and, based on its primacy in the World Health Organization classification of function and disability [11], this seems to be appropriate. However, it remains unclear whether generic QoL tools are appropriately responsive and have adequate construct validity to describe key domains of patient's experience after critical illness. In a recent study evaluating measures of health-related QoL, substantial gaps in the coverage of important aspects of survivorship were reported, including finances, place of residence, appearance and personality [12]. The 36-Item Short Form Health Survey (SF-36) demonstrated a moderate to strong correlation with anxiety and depression symptoms from specific psychological screening tools, but with a low specificity for mental health disorders [13]. The authors noted that because negative predictive values were high, the best use of the SF-36 in studies is to help rule out patients with mental health disorders.

Power One of the most important aspects of trial design is the sample size required to detect a difference between groups. Ideally, sample size calculations are determined from studies in a similar group of patients with the same intervention or from similar previous studies that used the outcome measure planned in the proposed trial. This is particularly important when the aim of the study is to detect a small difference between the groups. A systematic review of QoL after critical illness found that the mental health domain differed the least from norms and, consequently, may be a signal that is difficult to detect [14].

Control group The purpose of a control group is to provide a comparator where the independent variable being tested cannot influence the results. One of the difficulties of pragmatic clinical trials is where a control group receives "standard care" where co-interventions may indeed influence the independent variable. In this and

Table 1 Patient and trial characteristics in larger $(n>100)$ intensive care unit follow-up trials

\begin{tabular}{|c|c|c|c|c|c|c|c|c|c|c|c|}
\hline Trial & $\mathbf{N}$ & Patient group & $\begin{array}{l}\text { Nature of } \\
\text { intervention }\end{array}$ & $\begin{array}{l}\text { Timing of } \\
\text { Intervention }\end{array}$ & $\begin{array}{l}\text { Team delivering } \\
\text { intervention }\end{array}$ & Control group & $\begin{array}{l}\text { Primary } \\
\text { Outcome }\end{array}$ & \begin{tabular}{l|} 
Primary \\
outcome \\
timing (max \\
follow up)
\end{tabular} & Effect & $\begin{array}{l}\text { Power based on } \\
\text { previous data } \\
\text { from similar } \\
\text { population }\end{array}$ & $\begin{array}{l}\text { Loss to follow } \\
\text { up at } \\
\text { maximal } \\
\text { follow up } \\
\text { time point }\end{array}$ \\
\hline \multicolumn{12}{|c|}{ Studies showing benefit } \\
\hline $\begin{array}{c}\text { Jones } \text { et al } \\
2010[7]\end{array}$ & 352 & $\begin{array}{c}\text { ICU admissions } \\
\text { (ventilated } \\
\text { for }>72 \text { hours) }\end{array}$ & ICU diaries & $\begin{array}{l}\text { One month after } \\
\text { ICU discharge }\end{array}$ & $\begin{array}{l}\text { Nurse led within } \\
\text { ICU team }\end{array}$ & Usual care & $\begin{array}{c}\text { Not stated but } \\
\text { study powered } \\
\text { on new } \\
\text { diagnosis of } \\
\text { PTSD }\end{array}$ & $\begin{array}{l}3 \text { months } \\
\text { (3 month) }\end{array}$ & $\begin{array}{c}\text { Benefit for } \\
\text { intervention }\end{array}$ & $\begin{array}{l}\text { Yes (previous } \\
\text { cohort study) }\end{array}$ & $\begin{array}{c}\text { 3\%, non- } \\
\text { differential }\end{array}$ \\
\hline \multicolumn{12}{|c|}{ Studies showing no effect } \\
\hline $\begin{array}{l}\text { Cuthbertson } \\
\text { et al 2009[2] }\end{array}$ & 286 & $\begin{array}{l}\text { Ventilated ICU } \\
\text { admissions }\end{array}$ & \begin{tabular}{c|} 
Complex \\
intervention (with \\
physical and \\
psychological \\
interventions)
\end{tabular} & $\begin{array}{l}\text { Hospital (after } \\
\text { ICU stay) - } 9 \\
\text { months after } \\
\text { discharge }\end{array}$ & $\begin{array}{l}\text { Nurse led within } \\
\text { ICU team }\end{array}$ & $\begin{array}{c}\text { Usual care } \\
\text { (no rehabilitation) }\end{array}$ & $\begin{array}{c}\text { Quality of life } \\
\text { (SF-36) }\end{array}$ & \begin{tabular}{c|}
12 months \\
(12 months)
\end{tabular} & No effect & $\begin{array}{l}\text { Anchored using } \\
\text { standard } \\
\text { deviations }\end{array}$ & $\begin{array}{c}17 \%, \\
\text { differential } \\
\text { towards } \\
\text { treatment } \\
\text { group }\end{array}$ \\
\hline $\begin{array}{l}\text { Elliot et al } \\
2011[16]\end{array}$ & 195 & $\begin{array}{c}\text { ICU } \\
\text { admissions } \\
\text { (ventilated } \\
\text { for }>24 \\
\text { hours) }\end{array}$ & Physical therapy & $\begin{array}{c}\text { After hospital } \\
\text { discharge - } 8 \\
\text { weeks }\end{array}$ & $\begin{array}{l}\text { Physiotherapists, } \\
\text { nurse or exercise } \\
\text { physiologist }\end{array}$ & $\begin{array}{c}\text { Usual care } \\
\text { (no rehabilitation) }\end{array}$ & $\begin{array}{l}\text { Physical } \\
\text { function } \\
\text { (SF-36) }\end{array}$ & $\begin{array}{l}6 \text { months } \\
\text { (6 months) }\end{array}$ & No effect & No & $\begin{array}{l}4 \% \text {, non- } \\
\text { differential }\end{array}$ \\
\hline $\begin{array}{c}\text { Walsh et al } \\
\text { 2015[17] }\end{array}$ & 240 & $\begin{array}{l}\text { ICU admissions } \\
\text { (ventilated } \\
\text { for }>48 \text { hours) }\end{array}$ & $\begin{array}{c}\text { Complex } \\
\text { intervention } \\
\text { (including } \\
\text { dedicated } \\
\text { rehatilitation } \\
\text { practitioner) }\end{array}$ & $\begin{array}{l}\text { ICU stay - 3 } \\
\text { months }\end{array}$ & ICU team & $\begin{array}{c}\text { Usual care } \\
\text { (including ICU } \\
\text { rehabilitation } \\
\text { manual) }\end{array}$ & $\begin{array}{c}\text { Physical } \\
\text { function score } \\
\text { (Rivermead } \\
\text { Mobility Index) }\end{array}$ & $\begin{array}{c}3 \text { months } \\
\text { (12 months) }\end{array}$ & No effect & Pilot data & $\begin{array}{c}24 \% \text {, possibly } \\
\text { differential } \\
\text { towards } \\
\text { control group }\end{array}$ \\
\hline $\begin{array}{c}\text { Morris et al } \\
2016[10]\end{array}$ & 300 & $\begin{array}{l}\text { Ventilated ICU } \\
\text { admissions }\end{array}$ & Physical therapy & $\begin{array}{c}\text { ICU stay - } \\
\text { hospital } \\
\text { discharge }\end{array}$ & $\begin{array}{l}\text { Physiotherapist led } \\
\text { within ICU team }\end{array}$ & $\begin{array}{c}\text { Usual care } \\
\text { (including } \\
\text { physiotherapy) }\end{array}$ & $\begin{array}{c}\text { Hospital length } \\
\text { of stay } \\
\text { (days) }\end{array}$ & $\begin{array}{l}\text { Hospital } \\
\text { discharge } \\
(6 \text { months })\end{array}$ & No effect & No & $21 \%$ \\
\hline $\begin{array}{l}\text { Moss et al } \\
\text { 2016[15] }\end{array}$ & 120 & $\begin{array}{l}\text { Ventilated } \\
\text { ICU } \\
\text { admissions }\end{array}$ & Physical therapy & $\begin{array}{c}\text { ICU stay for } 28 \\
\text { days }\end{array}$ & ICU team & $\begin{array}{c}\text { Usual care } \\
\text { (including } \\
\text { physiotherapy) }\end{array}$ & $\begin{array}{l}\text { Physical } \\
\text { function } \\
\text { (PFP score) }\end{array}$ & $\begin{array}{c}1 \text { month } \\
\text { (6 months) }\end{array}$ & No effect & Yes & $\begin{array}{c}\text { 34\% observed, } \\
\text { non- } \\
\text { differential }\end{array}$ \\
\hline $\begin{array}{c}\text { Jensen } \text { et al } \\
2016[1]\end{array}$ & 386 & $\begin{array}{l}\text { ICU admissions } \\
\text { (ventilated } \\
\text { for }>48 \text { hours) }\end{array}$ & $\begin{array}{c}\text { Complex } \\
\text { intervention } \\
\text { (including diaries) }\end{array}$ & $\begin{array}{l}1-10 \text { months } \\
\text { after ICU } \\
\text { admission }\end{array}$ & $\begin{array}{l}\text { Nurse led within } \\
\text { ICU team }\end{array}$ & $\begin{array}{c}\begin{array}{c}\text { Usual care } \\
\text { (including } \\
\text { rehabilitation care) }\end{array} \\
\end{array}$ & $\begin{array}{l}\text { Mental health } \\
\text { quality of life } \\
\text { (SF-36) }\end{array}$ & $\begin{array}{c}12 \text { months } \\
\text { (12 months) }\end{array}$ & No effect & No & $\begin{array}{c}\text { Unclear } \\
\text { but }>\mathbf{2 0} \% \text {, } \\
\text { possibly } \\
\text { differential }\end{array}$ \\
\hline
\end{tabular}

The specific study characteristics which may have contributed to the results are highlighted in bold

ICU Intensive care unit, ADL Activities of Daily Living Inventory, PTSD posttraumatic stress disorder, SF-36 36-Item Short Form Health Survey, PFP physical function performance 
other cases, it may be ethically difficult for investigators to remove any treatment that is considered "standard care" in the trial centers, even though the evidence base may not support the practice $[1,5]$. In the RAPIT study [1], the authors discuss the potential limitations of the control group who received a significant amount of physical rehabilitation, a factor that may have an impact on mental health outcomes in the control group, thus reducing the magnitude of any effect. In this field, as is so often the case, the specification of the control group may be more even important than specifying the intervention.

Retention An important consideration of interventional studies that measure long-term outcomes following critical illness is the fidelity of the intervention and loss to follow-up [15]. In the RAPIT study the intervention was not delivered to $28 \%$ of recruited patients [1]. Loss to followup can introduce a bias if it is differential and particularly if attributable to the outcome being measured-for example if mental health issues are responsible for patient loss. Research in long-term outcomes following critical illness needs to consider improved methodologies and registry linkages to accurately determine long term outcomes.

Despite our best efforts, effective interventions after ICU care to improve patient-centered outcomes remain elusive, and many of our interventions have been proven to be ineffective (Table 1). In order to achieve progress in the field and, most importantly, to improve outcomes for our patients, we need to recruit the right patients, at the right time in their disease trajectories, using interventions designed and delivered by a care team with the appropriate skills and expertise. Currently, we may not have sufficient knowledge to identify some or even many of these factors.

\section{Author details}

${ }^{1}$ ANZIC Research Centre, Melbourne, Australia. ${ }^{2}$ Department of Critical Care Medicine, Sunnybrook Health Sciences Centre and University of Toronto, 2075 Bayview Avenue, D-wing, 1st floorroom D1 08, Toronto, ON M4N 3M5, Canada.

\section{Compliance with ethical standards}

\section{Conflicts of interest}

The authors have no conflicts of interest to report.

Received: 22 August 2016 Accepted: 23 August 2016

Published online: 30 September 2016
2. Cuthbertson BH, Rattray J, Campbell MK, Gager M, Roughton S, Smith A, Hull A, Breeman S, Norrie J, Jenkinson D, Hernandez R, Johnston M, Wilson E, Waldmann C (2009) The PRaCTICaL study of nurse led, intensive care follow-up programmes for improving long term outcomes from critical illness. BMJ 339:b3723

3. Cuthbertson BH, Wunsch $H$ (2016) Long-term outcomes after critical illness. the best predictor of the future is the past. Am J Respir Crit Care Med 194:132-134

4. Rabiee A, Nikayin S, Hashem MD, Huang M, Dinglas VD, Bienvenu OJ, Turnbull AE, Needham DM (2016) Depressive symptoms after critical illness: a systematic review and meta-analysis. Crit Care Med 44(9):1744-1753

5. Denehy L, Skinner EH, Edbrooke L, Haines K, Warrillow S, Hawthorne G, Gough K, Hoorn SV, Morris ME, Berney S (2013) Exercise rehabilitation for patients with critical illness: a randomized controlled trial with 12 months of follow-up. Crit Care 17:R156

6. Iwashyna TJ, Burke JF, Sussman JB, Prescott HC, Hayward RA, Angus DC (2015) Implications of heterogeneity of treatment effect for reporting and analysis of randomized trials in critical care. Am J Respir Crit Care Med 192:1045-1051

7. Jones C, Backman C, Capuzzo M, Egerod I, Flaatten H, Granja C, Rylander C, Griffiths RD (2010) Intensive care diaries reduce new onset post traumatic stress disorder following critical illness: a randomised, controlled trial. Crit Care 14:R168

8. Hodgson CL, Iwashyna TJ, Schweickert WD (2016) All that work and no gain - what should we do to restore physical function in our survivors? Am J Respir Crit Care Med 15:1071-1072

9. Schweickert WD, Pohlman MC, Pohlman AS, Nigos C, Pawlik AJ, Esbrook CL, Spears L, Miller M, Franczyk M, Deprizio D, Schmidt GA, Bowman A, Barr R, McCallister KE, Hall JB, Kress JP (2009) Early physical and occupational therapy in mechanically ventilated, critically ill patients: a randomised controlled trial. Lancet 373:1874-1882

10. Morris PE, Berry MJ, Files DC, Thompson JC, Hauser J, Flores L, Dhar S, Chmelo E, Lovato J, Case LD, Bakhru RN, Sarwal A, Parry SM, Campbell P, Mote A, Winkelman C, Hite RD, Nicklas B, Chatterjee A, Young MP (2016) Standardized rehabilitation and hospital length of stay among patients with acute respiratory failure: a randomized clinical trial. JAMA 315:2694-2702

11. World Health Organization (2001) ICF: International Classification of Functioning, Disability and Health. World Health Organization, Geneva

12. Lim WC, Black N, Lamping D, Rowan K, Mays N (2016) Conceptualizing and measuring health-related quality of life in critical care. J Crit Care 31:183-193

13. Pfoh ER, Chan KS, Dinglas VD, Cuthbertson BH, Elliott D, Porter R, Bienvenu OJ, Hopkins RO, Needham DM (2016) The SF-36 offers a strong measure of mental health symptoms in survivors of acute respiratory failure. A tri-national analysis. Ann Am Thorac Soc 13:1343-1350

14. Dowdy DW, Eid MP, Dennison CR, Mendez-Tellez PA, Herridge MS, Guallar E, Pronovost PJ, Needham DM (2006) Quality of life after acute respiratory distress syndrome: a meta-analysis. Intensive Care Med 32:1115-1124

15. Moss M, Nordon-Craft A, Malone D, Van Pelt D, Frankel SK, Warner ML, Kriekels W, McNulty M, Fairclough DL, Schenkman M (2016) A randomized trial of an intensive physical therapy program for patients with acute respiratory failure. Am J Respir Crit Care Med 193:1101-1110

16. Elliott D, McKinley S, Alison J, Aitken LM, King M, Leslie GD, Kenny P, Taylor P, Foley R, Burmeister E (2011) Health-related quality of life and physical recovery after a critical illness: a multi-centre RCT of a home-based physical rehabilitation program. Crit Care 15:R142

17. Walsh TS, Salisbury LG, Merriweather JL, Boyd JA, Griffith DM, Huby G, Kean S, Mackenzie SJ, Krishan A, Lewis SC, Murray GD, Forbes JF, Smith J, Rattray JE, Hull AM, Ramsay P (2015) Increased hospital-based physical rehabilitation and information provision after intensive care unit discharge: the recover randomized clinical trial. JAMA Intern Med 175:901-910

\section{References}

1. Jensen JF, Egerod I, Bestle MH, Christiensen DF, Elklit A (2016) Improving quality of life and psychological recovery in post-intensive care patients: a pragmatic multicenter randomized controlled trial, The RAPIT study. Intensive Care Med (in press) 